Journal of Teacher Education for Sustainability, vol. 21, no. 1, pp. 128-136, 2019

\title{
Discourse Analysis and Language Pedagogy: A Review
}

\author{
Alireza Bonyadi \\ Islamic Azad University, Urmia, Iran
}

\begin{abstract}
Taking discourse approach towards language teaching has been drawing researchers' and practitioners' attention since the introduction of discourse analysis as a discipline in social sciences. Based on the premise that education for sustainable development (ESD) in language pedagogy cannot be realized fully unless language teachers are equipped with theoretical issues in discourse analysis, the purpose of this paper is to review the current research on discourse analysis and language teaching. The focus on the intersection of discourse analysis and language education indicates that three approaches, namely Critical discourse analysis, Descriptive discourse analysis, and Pedagogical discourse analysis have been taken by practitioners in educational context. As for directions of future research on discourse analysis and language teaching, it was postulated that the prospective researchers in the field are expected to focus on operationalizing the discourse concepts at the methodological level. This would be possible if EFL/ESL teachers themselves truly get educated in a discourse-based program in teacher education centers.
\end{abstract}

Keywords: discourse analysis, language teaching, pedagogical discourse, critical discourse analysis, genre analysis.

\section{Introduction}

Language teaching in general and EFL teaching practice in particular have gone through different phases based on the then emerging related pedagogical teaching theories. However, the common resulting theme of employing these theories is almost the same. Students are still having difficulties with their learned "Englishes" in spite of their ability in perceiving and production of linguistically acceptable words, phrases, and sentences (Lezberg \& Hilferty, 1978; Olshtain \& Celce-Murcia, 2001).

Moreover, the prevalent communicative approach to language teaching with its emphasis on mastering communicative strategies such as inferencing, paraphrasing, using circumlocution, avoidance, - just to name a few - has not resulted in any radical change in the status quo as was expected by the advocates (Cots, 1996; Jin \& Li, 2005; Rao, 2002). In other words, the approach is still lagging behind in developing students' real communicative competence. Of course, this inefficiency can be attributed to factors 
like the limited number of class hours, lack of opportunities to interact with natives, and little exposure to out-of-class genres and discourse types (Demo, 2001).

As a solution to the inefficiency of communicative approaches to language teaching, it was suggested that these approaches cannot be succeeded unless they are coupled with "language teachers and other teaching professionals (curriculum developers, textbook writers, language testers) with proper grounding in discourse analysis” (Olshtain \& Celce-Murcia, 2001, p. 721).

In fact, experimental and enquiry learning which are usually emphasized in language teaching can be realized through taking a discourse approach in EFL teaching. These strategies are the main objectives of education for sustainable development. (Teaching and Learning for a Sustainable Future, 2018)

Growing out of disciplines like linguistics, semiotics, psychology, anthropology and sociology, discourse analysis generally aims at studying language (both written and spoken) in context (McCarthy, 1991). Having said so, it seems that people in these different disciplines use the term discourse analysis to serve their intended purposes. In other words, they are posing different questions and then suggesting different answers (Johnstone, 2018).

Within the context of EFL teaching, discourse analysis can be defined as "how stretches of language, considered in their full textual, social, and psychological context, become meaningful and unified for their users" (Cook, 1990, p. 3). Based on this definition, some EFL practitioners, in line with Olshtain and Celce-Murcia's suggestion on grounding in discourse analysis, ventured out into incorporating discourse analysis in their practical teaching professions.

The phrase "ventured out "has purposefully used in the preceding paragraph as it is not that much feasible to adopt a discourse point of view in teaching a language unless one attempts initially to reconsider and modify some of his/her perceptions about language based on the following premises:

- The main focus of language teaching is communication,

- Context is of importance in shaping communication, and

- Meanings are exchanged dynamically in a speech event.

Considering the fact that communicative language teaching cannot be realized fully unless language teachers are equipped with theoretical issues in discourse analysis (Olshtain \& Celce-Murcia, 2001), and reconsider their perceptions on language, the next logical issue that should be addressed would be how we can put this theoretical knowledge into practice in the classrooms.

Moreover, it is predicted that the pedagogical consequence of taking such an approach in language teaching would result in a teaching methodology which is highly contextualized, full of authentic instances of language uses in different social situations (Cots, 1996).

The present paper, thus, attempts to review the published papers and reports on employing discourse analysis in English language teaching. As it is not practically possible to present all the published papers in the literature, only selected papers based on their typicality would be reported herewith. This review paper initially examines the papers to find out how discourse analysis has been integrated into language teaching practice. A conclusion has been drawn at the end of the review. 


\section{Discourse Analysis in Educational Context}

Based on the key concepts in discourse analysis focusing on how people use language in real life for communicating what they mean and also for doing what they want, some language practitioners in an effort to raise a conscious "awareness of numerous discourse conventions" (Belz, 2005, p. 342) have tried to "flavor" their teaching with different discourse approaches. Critical discourse analysis, Descriptive discourse analysis and Pedagogical discourse analysis are the approaches taken by some practitioners in educational context.

\section{Critical Discourse Analysis}

Critical discourse analysis defined as "an analytical research that primarily studies the way social power abuse, dominance, and inequality are enacted, reproduced, and resisted by text and talk in the social and political context" (Van Dijk, 2003, p. 352) has been employed in educational settings. In this setting, it aims at developing students' capacities in evaluating and scrutinizing the world as represented in texts and talks. In this way, the teachers go beyond linguistic training helping the students become critical thinkers something that has been ignored in our EFL teaching courses (Colt, 2006).

In an effort to demonstrate the application of Critical Discourse Analysis (CDA) in language teaching, Cots (2006) proposed some activities to be followed in teaching reading skills. Specifically and in line with Fairclough's (1992) analytical model, Cots presented three sets of questions pertained to three different levels of text analysis namely social, discursive and textual practices. He claimed that through using these questions, the teachers would be able to approach language use with a critical attitude.

Rahimi and Sharififar (2015) investigated the effect of using critical discourse analysis on students' reading skills. One of Obama's political speeches was presented to the students as a reading text. The students were asked to analyze the text once before attending critical discourse analysis (CDA) lectures and then after the lectures. Based on the comparison of the students' performance in analyzing the text and also their perceptions of the effect of CDA on their performance elicited through a questionnaire, the researchers concluded that CDA facilitated students' critical thinking ability. As an implication of the study, they suggested that instead of presenting factual texts, both teachers and syllabus designers should prefer ideologically loaded reading texts. Accordingly, they argued that teachers should focus on inferential questions in their reading classes.

Lezberg and Hilferty (1978) in an attempt to prepare students for successful communication in general and helping them in their EFL reading classes to "understand more fully the implications of their reading" (p. 49) in particular suggested focusing on plays as reading texts assuming that the genre includes "those covert elements of social interaction which control and transcend the meaning of each discrete word, sentence, or speech" (p. 50). Also, as an exercise for reading texts selected from current newspaper and magazines, they presented some tasks such as, skimming tasks, scanning tasks and activities, such as before-reading, after-reading exercises and some reading skill builders, such as timed reading exercises. Through doing these exercises, they anticipated that the students would stop fearing reading materials. Engaging as active participants, the students would ask questions and challenge ideas. 


\section{Pedagogical Discourse Analysis}

Discourse analysis as a heterogeneous field has also formed a backdrop to research in teaching language skills (McCarthy, 1991). Among the language skills, language practitioners have generally focused on reading and writing skills.

In an attempt to take a discourse approach in his reading class, Wu (2017) focused on aspects of discourse grammar, namely identifying and understanding reference and substitution, ellipsis, lexical cohesion, conjunctions and identifying the rhetorical structures. He claimed that using a discourse approach proved to be beneficial to his students as it enabled them to foster their logical thinking ability. The claim, of course, has not been substantiated by any statistics.

Khatib \& Safari (2011) explored the relationship between EFL students' knowledge of discourse markers and their reading comprehension. The findings of the study indicated a high correlation (.71) between the two variables. As an implications of the study, the researchers proposed discourse markers to be taught explicitly as it enhanced students' reading comprehension.

Based on his secondary research on the application of discourse analysis in EFL reading skill, Ivanov (2009) claimed that discourse analysis made a "paradigm shift" in teaching reading skills in that it first changed the focus from

- Linguistic study of text to study of language in use,

- Bottom-up/top-down approach to interactive approach, and

- Prior knowledge-oriented approach to awareness-oriented approach.

As implications of his study, Ivanov suggested that EFL teachers as well as syllabus designers should “delineate genres that are essential and relevant to particular learners' needs and to include them in class content and textbooks" (p. 25). Secondly, he claimed that a discourse oriented approach to language teaching would bring about a kind of "language awareness" on certain discourse structures and functions enabling the students to establish relationships between forms and functions. Finally, the approach would enable the teachers to evaluate their classroom interactions that would be of importance in designing classroom tasks.

Focusing on discourse in second language writing classrooms, Paltridge (2018) raised the notion of "genre" that he thought to be useful for teachers in teaching writing. Practically, he proposed a number of ways for focusing on discourse in general and genre in particular in ESL settings listed as below:

- Teachers can take a sample text and analyze it in the classroom to identify its rhetorical structures and moves. The outcome can be used as a model for students to draw on for their individual writings.

- Students are given a sample text/texts to be analyzed in terms of discourse structure in preparation for their own writings.

- Teachers can cut up texts into their discourse structures and then jumble them to get reassembled by the students. The original text, then, can be presented to the students for comparison purposes.

- Based on some key aspects of certain genres, students can be asked to write texts. They are then asked to critique each other's texts discussing their observations.

- Students can compose a text based on notes. Drawing on what they have already been taught, students are asked to write up the information on the cards in an accepted manner. (A kind of consolidation practice) 
- Students can be guided to focus on the thematic progression of a given text to figure out the flow of information in certain genre.

Through carrying out these classroom tasks, the students are expected to become familiar with "the ways of using language that are typical of different discourse communities” (Ibid, p. 662).

Kapanadze (2018) conducted a research on the effect of discourse oriented teaching on improving students' cognitive and effective skills. The findings of her study indicated that this way of teaching improved students' reading comprehension skills, their textual analysis and language use abilities.

Furthermore, the main themes emerged in her analysis of students' interviews on their perception on taking discourse-oriented classes were reported as enhancing students' thinking skills, meaningful learning, effective organization of ideas, native language awareness, and social skills.

Though the researcher had not elaborated fully on her claimed discourse-oriented method of teaching, she stated that "integration of discourse analysis method to language and literature lessons makes these lessons more interesting and attractive, and so it creates more opportunities for students to attend and actively participate in these lessons" (p. 104).

\section{Discourse Analysis as a Tool for Language Description}

The description of language above the sentence and the interest in the contexts and cultural influences which might affect language in use can be regarded as the common themes of different discourse approaches (McCarthy, 1991). In line with this general themes, some language practitioners undertook efforts to use discourse analysis as a tool for describing interaction patterns, discourse markers, teacher talk, and gender representations in EFL context. It is believed that through this approach of discourse, EFL/ESL teachers would be able to acquire a deeper understanding of the nature of classroom discourse providing them with a concrete framework for tuning their classroom activities (Belz, 2005).

Acknowledging the limitations of communicative approaches in developing communicative competence of ESL students, Demo (2001) proposed a four-part process of Record-View-Transcribe-Analyze to study teachers' classroom interaction patterns. Furthermore, to expose learners to different discourse patterns, he encouraged teachers to make the students do discourse analysis of natural language use in different contexts enabling them to get a deeper "understanding of the discourse patterns associated with a given genre or speech event as well as the sociolinguistic factors that contribute to linguistic variation across settings and contexts" (p. 4).

Employing a qualitative approach, Sulaimani (2017) investigated gender representation in listening comprehension texts included in English textbooks used in Saudi university. The study revealed that textbook material underrepresented females. He supported the claim through indicating the fact that men were represented more frequently than women. Moreover, the number of men occurring in subject position outnumbered the women. The study came to conclusion that the "biased representation of gender in textbooks would hinder the process of women empowerment" (p. 50).

Modhish (2012) investigated the use of discourse markers (DM) that Yemeni EFL learners used in their composition writings. The study also explored the possible relation- 
ship between the use of such markers and the writing quality of the learners. Based on Fraser's taxonomy, the researcher reported that the most frequently used discourse markers were: the elaborative, inferential, contrastive, causative and topic relating markers. The statistical analysis of the data, however, indicated no positive correlation between students' total number of discourse markers used and their writing quality. It was recommended that EFL teachers should focus on DMs both inductively and deductively in their classes.

In line with the above-mentioned study, Özer and Okan (2018), through a corpus based study, explored the frequency and the types of discourse markers (DM) used by Turkish teachers and native teachers in EFL classrooms. The results of the study indicated that Turkish teachers used DMs with a less variety compared to native teachers in EFL classrooms. Turkish teachers in this study were found to use 29 different DMs like ("okay", "and", “yes", etc.). Native teachers, on the other hand, used additionally 37 different DMs like ("you know what", "to begin with”, “you see”, etc.). The researchers, thus, highlighted the "necessity of raising nonnative English language teachers' awareness towards the significance of DMs in the spoken discourse" (p. 62).

Using conversational analysis as a framework, Gharbavia and Iravani (2014) investigated the quality and efficiency of teacher talk addressing the research question if the talk facilitates or otherwise EFL students' language use. The study reported that teacher talk in most cases was "repetitive and monotonous" making the students anxious and stressful and thus blocking their learning processes.

\section{Conclusion}

Since "international awareness about sustainability was first introduced at the United Nations UNESCO-UNEP International Educational Program” (Iliško, Oḷehnoviča, Ostrovska, Akmene, \& Salīte, 2017, p. 103), language practitioners have tried to incorporate concepts and ideas proposed by different approaches of discourse analysts into their practical language classrooms trying to get closer to education for sustainable development in language pedagogy. The present review paper indicated that among different discourse approaches, Critical Discourse Analysis (CDA), Descriptive Discourse Analysis (DDA), and Pedagogical Discourse Analysis (PDA) were the approaches taken by some practitioners in educational context. Helping students become critical thinkers besides mastering the basic linguistic structures of the target language was the aim pursued by critical discourse analysis in educational context. Through Descriptive Discourse Analysis, practitioners aimed at describing language above the sentence taking into consideration respective educational context. Pedagogical Discourse Analysis examined the effect of different discourse variables on teaching language skills.

The two initial approaches namely CDA and DDA are of importance in language education in that they acquaint the learners with the natural language use in authentic environments assisting them to deepen their appreciation of the discourse patterns associated with a certain genre that is not possible otherwise (Demo, 2011). In other words, the approaches provide the "students with the language resources and skills which will help them gain access to academic discourse communities" (Paltridge, 2018, p. 2).

The third approach, PDA, aimed at making use of the findings put forward by CDA and DDA in educational contexts which in fact opens a new dimension in language 
teaching practice. However, the review indicated that the approach has focused more on reading and writing skills than speaking and listening. Acknowledging the importance of speaking and listening skills in developing communicative competence of the students, scholars who are taking PDA approach should shift their attention to these skills as well.

The other issue the researcher in this field, PDA, are expected to do is exploring the practical ways for incorporating further concepts of discourse analysis in EFL classrooms. The point is that how it would be possible to teach explicitly or otherwise, say, text interpretations strategies such as schematic knowledge, frames of reference, background knowledge, or conversation strategies like turn-taking, repairs, giving feedbacks or any other aspects of discourse that do play a role in enabling the learners to make sense of a piece of discourse or get engaged in an interaction in a certain context?

It seems that there is a common consensus among EFL teachers that sustained educational development as "a multi-disciplinary subject" (Anyolo \& Keinonen, 2018, p. 64) would not be realized unless a discourse approach in language teaching has been taken. However, the issue of realization of the approach in educational settings has not been explored fully. In fact, to transit from an approach level to a methodology level, we should come up with a design for an instructional system which includes objectives, content, learning tasks, teacher/learner role and instructional materials (Richard \& Rogers, 2014). In other words, the prospective researchers on the field should focus on operationalizing the discourse concepts in methodological level.

Finally, even if we do manage in transition from approach level to methodology level, there would be no guarantee, however, for taking a full-fledged pedagogical discourse approach unless our EFL/ESL teachers themselves truly get educated in a discoursebased program. Through teacher training centers "teacher candidates reach a synthesis about what to become and what not to become when they graduate and become an inservice teacher" (Atmaca, 2017, p. 79). Thus, language teacher training centers are expected to take required measured in this regard tuning themselves with the recent approaches in EFL/ESL instruction. In fact, it would be both unethical and illogical to expect teachers to teach in a certain way for which they have not well prepared.

To reorient teacher education to address sustainability, the major tenets of sustainable development should be applied to education and teacher education (Ghaemi \& Kargozari, 2011). In this way, as it has been highlighted by Sunda (2016), it is hoped that through considering language learning and teaching as a part of education for sustainable development we would be able to change our students to critical and independent thinkers questioning current behavior and patterns of life style.

\section{References}

Anyolo, E. O., Kärkkäinen, S., \& Keinonen, T. (2018). Implementing education for sustainable development in Namibia: School teachers' perceptions and teaching practices. Journal of Teacher Education for Sustainability, 20(1), 64-81.

Atmaca, Ç. (2017). Effects of contextual factors on ESD in teacher education. Discourse and Communication for Sustainable Education, 8(2), 77-93.

Belz, J. A. (2005). Discourse analysis and foreign language teacher education. In Applied linguistics and language teacher education (pp. 341-363). Boston, MA: Springer. 
Cook, G. (1990). Discourse. Oxford: Oxford University Press.

Cots, J. M. (1996). Bringing discourse analysis into the language classroom. Links \& Letters, 3, 77-101.

Cots, J. M. (2006). Teaching 'with an attitude': Critical discourse analysis in EFL teaching. ELT Journal, 60(4), 336-345.

Demo, D. A. (2001). Discourse analysis for language teachers (Report No. ED456672). ERIC Clearinghouse on Languages and Linguistics Washington DC. ERIC Digest. Retrieved from ERIC database.

Fairclough, N. (1992). Discourse and social change. Oxford: Blackwell.

Ghaemi, H., \& Kargozari, H. (2011). An investigation into the elements of the international English language testing system: Instructors' success. Journal of Teacher Education for Sustainability, 13(1), 84-98.

Gharbavi, A., \& Iravani, H. (2014). Is teacher talk pernicious to students? A discourse analysis of teacher talk. Procedia-Social and Behavioral Sciences, 98, 552-561.

Iliško, D., Oḷehnoviča, E., Ostrovska, I., Akmene, V., \& Salìte, I. (2017). Meeting the challenges of ESD competency-based curriculum in a vocational school setting. Discourse and Communication for Sustainable Education, 8(2), 103-113.

Ji, Y. (2015). Discourse analysis and development of English listening for non-English majors in China. English Language Teaching, 8(2), 134.

Jin, L., Singh, M., \& Li, L. (2005, November). Communicative language teaching in China: Misconceptions, applications and perceptions. A paper presented at AARE' 05 Education Research. Parramatta, Sydney.

Johnstone, B. (2018). Discourse analysis ( $3^{\text {rd }}$ Ed.). New York: John Wiley \& Sons.

Ivanov, S. (2009). Discourse analysis in EFL reading. Unpublished MA thesis, Malmö University, Sweden.

Kapanadze, D. Ü. (2018). The effect of using discourse analysis method on improving cognitive and affective skills in language and literature teaching. European Journal of Education Studies, 4(5), 92-107.

Khatib, M., \& Safari, M. (2011). Comprehension of discourse markers and reading Comprehension. English Language Teaching, 4(3), 243-250.

Lezberg, A., \& Hilferty, A. (1978). Discourse analysis in the reading class. TESOL quarterly, 47-55.

McCarthy, M. (1991). Discourse analysis for language teachers. Cambridge: Cambridge University Press.

McCarthy, M. \& Carter, R. (1994). Language as discourse: Perspectives for language teaching. London: Longman.

Modhish, A. S. (2012). Use of discourse markers in the composition writings of Arab EFL learners. English Language Teaching, 5(5), 56-74.

Olshtain, E., \& Celce-Murcia, M. (2001). Discourse Analysis and Language Teaching. In D. Tannen, H. E. Hamilton, \& D. Schiffrin (Eds.), The handbook of discourse analysis (pp. 707- 724). Massachusetts: Blackwell Publishers Inc.

Özer, H. Z., \& Okan, Z. (2018). Discourse markers in EFL classrooms: A corpusdriven research. Journal of Language and Linguistic Studies, 14(1), 50-66.

Paltridge, B. (2018). Discourse analysis for the second language writing classroom. In J. I. Liontas (Ed.), TESOL encyclopedia of English language teaching. WileyBladewell. 
Rahimi, E., \& Sharififar, M. (2015). Critical discourse analysis and its implication in English language teaching: A case study of political text. Theory and Practice in Language Studies, 5(3), 504-511.

Rao, Z. (2002). Chinese students' perceptions of communicative and non-communicative activities in EFL classroom. System, 30, 85-105.

Richards, J. C., \& Rodgers, T. S. (2014). Approaches and methods in language teaching. Cambridge: Cambridge University Press.

Sulaimani, A. (2017). Gender representation in EFL textbooks in Saudi Arabia: A fair deal? English Language Teaching, 10(6), 44-52.

Sundh, S. (2016). A corpus of young learners' English in the Baltic Region texts for studies on sustainable development. Discourse and Communication for Sustainable Education, 7(2), 92-104.

Van Dijk, T. A. (2003). Critical discourse analysis. In D. Tannen, H. E. Hamilton, \& D. Schiffrin (Eds.), The handbook of discourse analysis (pp. 352-371). Massachusetts: Blackwell Publishing Ltd.

Wu, Y. (2017). Application and teaching implication of discourse analysis in reading comprehension. Advances in Intelligent Systems Research, 156, 513-517.

Teaching and learning for a sustainable future. (2018). Available from http://www. unesco.org/education/tlsf/

Correspondence concerning this paper should be addressed to Alireza Bonyadi, Assistant professor of Teaching English as a Second Language, English Language Department, Urmia Branch, Islamic Azad University, 57169-63896, Urmia, Iran. Email: a.bonyadi@iaurmia.ac.ir 